\title{
Bacteria-immobilized electrospun fibrous polymeric webs for hexavalent chromium remediation in water
}

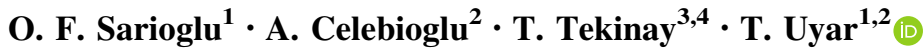

Received: 5 March 2016/Revised: 22 April 2016/Accepted: 21 May 2016/Published online: 2 June 2016

(C) Islamic Azad University (IAU) 2016

\begin{abstract}
The development of hexavalent chromium remediating fibrous biocomposite mats through the immobilization of a hexavalent chromium reducing bacterial strain, Morganella morganii STB5, on the surfaces of electrospun polystyrene and polysulfone webs is described. The bacteria-immobilized biocomposite webs have shown removal yields of 93.60 and $93.79 \%$ for $10 \mathrm{mg} / \mathrm{L}, 99.47$ and $90.78 \%$ for $15 \mathrm{mg} / \mathrm{L}$ and 70.41 and $68.27 \%$ for $25 \mathrm{mg} / \mathrm{L}$ of initial hexavalent chromium within $72 \mathrm{~h}$, respectively, and could be reused for at least
\end{abstract}

five cycles. Storage test results indicate that the biocomposite mats can be stored without losing their bioremoval capacities. Scanning electron microscopy images of the biocomposite webs demonstrate that biofilms of M. morganii STB5 adhere strongly to the fibrous polymeric surfaces and are retained after repeated cycles of use. Overall, the results suggest that reusable bacteria-immobilized fibrous biocomposite webs might be applicable for continuous hexavalent chromium remediation in water systems.
Electronic supplementary material The online version of this article (doi:10.1007/s13762-016-1033-0) contains supplementary material, which is available to authorized users.

T. Uyar

uyar@unam.bilkent.edu.tr

1 Institute of Materials Science and Nanotechnology, Bilkent University, 06800 Bilkent, Ankara, Turkey

2 UNAM-National Nanotechnology Research Center, Bilkent University, 06800 Bilkent, Ankara, Turkey

3 Department of Medical Biology and Genetics, Faculty of Medicine, Gazi University, 06500 Besevler, Ankara, Turkey

4 Life Sciences Application and Research Center, Gazi University, 06830 Golbasi, Ankara, Turkey 


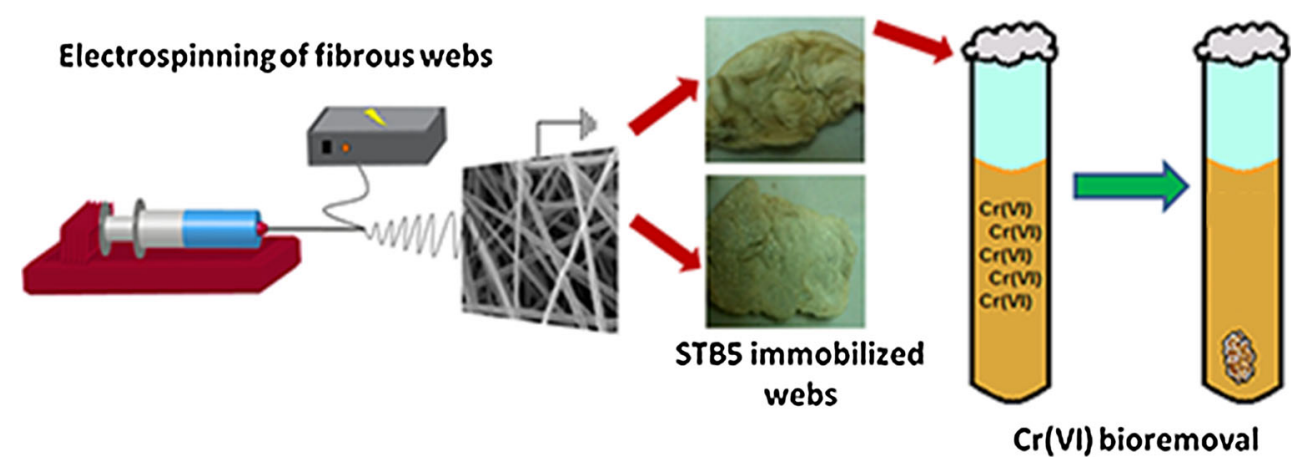

Keywords Bioremoval - Electrospinning · Polystyrene · Polysulfone

\section{Introduction}

Chromium is a commercially important metallic element that is integral for many important industrial processes, such as electroplating, steel production, leather tanning, textile manufacturing and chromate preparation (Quintelas et al. 2009). The trivalent ( $\mathrm{Cr}(\mathrm{III}))$ and hexavalent ( $\mathrm{Cr}(\mathrm{VI})$ ) forms are the most commonly encountered forms in nature (Bankar et al. 2009). While $\mathrm{Cr}$ (III) is not transported into cells and can be tolerated by many organisms at moderate concentrations, $\mathrm{Cr}(\mathrm{VI})$ is a toxic and carcinogenic form that readily permeates through biological membranes and may disrupt the functions of intracellular proteins and nucleic acids (Kilic and Donmez 2008). Chromium has been designated as a major pollutant by the United States Environmental Protection Agency (US EPA), and the legal limit defined for all forms of chromium, including $\mathrm{Cr}(\mathrm{VI})$, in drinking water is $0.1 \mathrm{mg} / \mathrm{L}$ (US EPA 2010). Heavy metal contamination in water systems can be treated by physical or chemical treatment methods (e.g., chemical oxidation or reduction, ion exchange, reverse osmosis) (Zahoor and Rehman 2009). However, there are several problems related with these techniques such as high operating and maintenance costs, high energy requirements, operational complexity and the production of secondary waste products (Mishra and Doble 2008). Today, biological treatment methods have received considerable attention as potential alternatives to conventional treatment methods (Mishra and Doble 2008; Quintelas et al. 2008; Al-Gheethi et al. 2014). In general, bioremediation of heavy metals is performed under acidic $\mathrm{pH}$, since the existence of excess hydrogen ions in the medium facilitates the reduction of metal cations, resulting in higher removal efficiencies (ErgulUlger et al. 2014). However, these are not self-sustaining and require the constant influx of externally produced biomass, as most microorganisms cannot tolerate acidic environments and perish rapidly under such conditions. In addition, the water system must be further treated for neutralization before discharge. For that reason, bioremediation at neutral conditions with living microorganisms is a more eco-friendly process and allows metal removal to occur continuously without external intervention. Morganella morganii STB5 is a bacterial strain previously isolated for this purpose and can be used for the effective removal of $\mathrm{Cr}(\mathrm{VI})$ at neutral conditions.

Carrier materials can be used to enhance the heavy metal removal capacities of bioremediative organisms (Yang et al. 2009). Electrospun nanofibers are popular choices as carrier materials, and they have already been studied for pollutant removal (Chauhan et al. 2014; Xu et al. 2015). Polystyrene (PS) and polysulfone (PSU) are two common biocompatible polymers (Pinchuk 1989) that have been used for water filtration, and there are various examples in the literature about the applications of these polymers as electrospun nanofibers for filtering purposes (Gopal et al. 2007; Roso et al. 2008; Uyar et al. 2009, 2010). Studies regarding the use of microorganism-integrated electrospun fibrous biocomposites for pollutant removal have recently begun to appear in the literature (Klein et al. 2009; Eroglu et al. 2012; Klein et al. 2012; Sarioglu et al. 2013; San et al. 2014; San-Keskin et al. 2015a, b; Sarioglu et al. 2015). Lower space and growth medium requirements, ease of handling and potential reusability of these systems are some of the main advantages for using them in remediation studies (Eroglu et al. 2012). Immobilization of microorganisms on a carrier matrix protects them from harsh environmental conditions and stresses associated with heavy metal toxicity (Hall-Stoodley et al. 2004). In addition, natural adhesion of bacteria permits the formation of biofilms and maximizes cell viability and biochemical activity (Liu et al. 2012).

In this study, development of two novel biocomposite materials for $\mathrm{Cr}(\mathrm{VI})$ removal in water by immobilization of 
Fig. 1 a Schematic representation of electrospinning process and photographs of PS and PSU webs, b photographs of STB5immobilized PS and c STB5immobilized PSU webs along with SEM micrographs and schematic representations of bacterial cells on fibrous surfaces

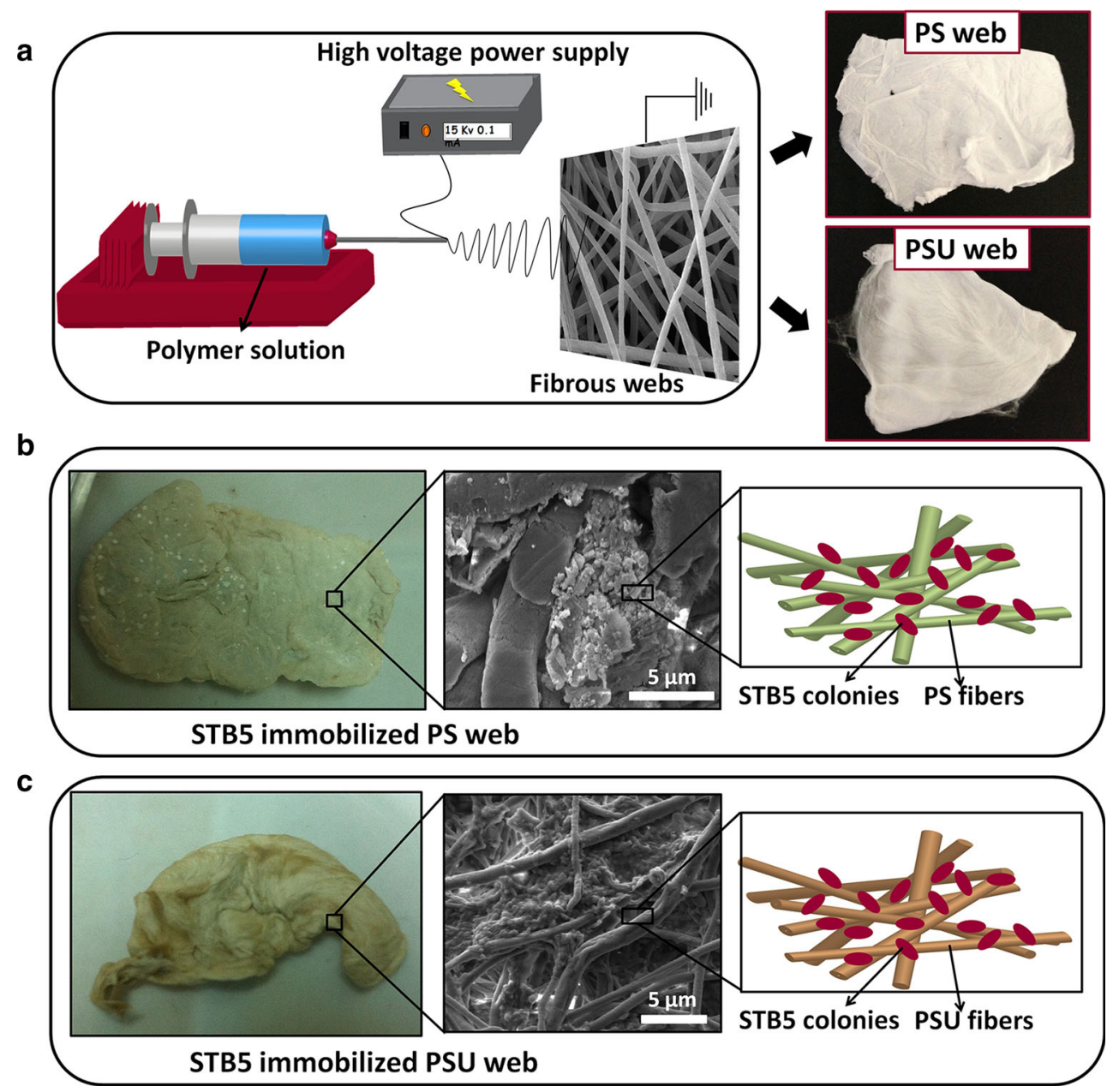

a previously isolated Morganella morganii STB5 strain on electrospun PS and PSU fibrous webs is described. Integration of PS and PSU webs with bacterial cells is aimed to be effective for continuous $\mathrm{Cr}(\mathrm{VI})$ remediation in aqueous systems. This study was carried out in Ankara, Turkey, between the years 2014 and 2016 .

\section{Materials and methods}

\section{Electrospinning of PS and PSU webs}

The homogenous electrospinning solution was prepared by dissolving $30 \%(\mathrm{w} / \mathrm{v})$ polystyrene (PS, Mw 208,000, Sigma-Aldrich) in $\mathrm{N}, \mathrm{N}$-dimethylformamide (DMF, anhydrous, $99.8 \%$, Sigma-Aldrich) or $32 \%$ (w/v) polysulfone (PSU, Mw $\sim 60,000$, Scientific Polymer Products, Inc.) in $N, N$-dimethylacetamide/acetone $(9 / 1,(\mathrm{v} / \mathrm{v}))$ (DMAC, Sigma-Aldrich, $99 \%$; acetone, Sigma-Aldrich, $\geq 99 \%$ (GC) binary solvent mixture. Each polymer solution was loaded in a syringe with an inner diameter of $0.4 \mathrm{~mm}$. The syringe was fixed horizontally to the syringe pump (model KDS-101, KD Scientific, USA). The electrode of the highvoltage power supply (Spellman, SL30, USA) was clamped to the metal needle tip, and the plate aluminum collector was grounded. Electrospinning parameters were adjusted as follows: feed rate of solutions $=0.5 \mathrm{~mL} / \mathrm{h}$, applied voltage $=10 \mathrm{kV}$, tip-to-collector distance $=10 \mathrm{~cm}$. Electrospun nanofibers were deposited on a grounded stationary plate metal collector covered with aluminum foil. The electrospinning apparatus was enclosed in a Plexiglas box, and electrospinning was performed at $25{ }^{\circ} \mathrm{C}$ at $20 \%$ relative humidity. Collected nanofibers/nanowebs were dried in vacuum oven at $50{ }^{\circ} \mathrm{C}$ overnight to remove residual solvent. The electrospinning process is schematically represented in Fig. 1.

\section{Contact angle measurements}

Thin surfaces of PS and PSU webs were electrospun on microscope slides to be analyzed with a contact angle measurement system (Dataphysis, OCA 30). Contact 
angles were measured over a relatively intact and smooth region for each web; three independent measurements were recorded for each sample. Measurements were performed in a closed chamber at ambient temperature.

\section{Growth and immobilization of Morganella morganii STB5}

The bacterial strain (Morganella morganii STB5) utilized in this study was previously isolated from a local river (Ankara River). Bacterial immobilization was achieved by the inclusion of PS or PSU webs in the growth media of newly inoculated bacteria. Bacterial colonies were maintained for 30 days in $100-\mathrm{mL}$ Erlenmeyer flasks containing M1 growth medium ( $\mathrm{pH}$ 7.0). The ingredients of $\mathrm{M} 1$ growth medium are: $10 \mathrm{~g} / \mathrm{L}$ peptone, $2 \mathrm{~g} / \mathrm{L}$ meat extract, $1 \mathrm{~g} / \mathrm{L}$ yeast extract and $5 \mathrm{~g} / \mathrm{L} \mathrm{NaCl}(\geq 99 \%)$ in distilled water. After 30 days of incubation, bacterial immobilization was confirmed by scanning electron microscopy (SEM) analysis. Following confirmation of bacterial immobilization, bacteria-immobilized PS and PSU web samples of equal weights were prepared for $\mathrm{Cr}(\mathrm{VI})$ bioremoval experiments. All reagents utilized were purchased from Sigma-Aldrich (USA).

\section{Cr(VI) bioremoval by using STB5/PS and STB5/ PSU biocomposite webs}

M1 growth medium was used in the $\mathrm{Cr}(\mathrm{VI})$ bioremoval studies, and all tests were performed in triplicate. The bacterial growth media were spiked with different amounts of $\mathrm{Cr}(\mathrm{VI})\left(10,15\right.$ and $25 \mathrm{mg} / \mathrm{L}$, in the form of $\mathrm{K}_{2} \mathrm{Cr}_{2} \mathrm{O}_{7}$, $\geq 99 \%$, Sigma-Aldrich) and inoculated with free bacterial cells, bacteria-free fibers or bacteria-immobilized fibers prior to incubation at $150 \mathrm{rpm}$ and $30{ }^{\circ} \mathrm{C}$ for $72 \mathrm{~h}$. The positive control contained free bacterial cells $\left(\sim 10^{8} \mathrm{cfu} / \mathrm{mL}\right)$, the negative control contained pristine fibers, and the experimental samples contained bacteria-immobilized PS or PSU fibers, where the w/v ratio of web samples was fixed as $2.8 \mathrm{mg} / \mathrm{mL}$. Samples were collected periodically to determine the remaining amount of $\mathrm{Cr}(\mathrm{VI})$. $\mathrm{Cr}(\mathrm{VI})$ concentrations were measured via 1,5-diphenylcarbazide, following the EPA protocol (US EPA 1992) for hexavalent chromium detection. The removal capacities $\left(Q_{\mathrm{eq}}\right)$ of free STB5 cells and STB5-immobilized web samples were calculated by Eq. (1)

$Q_{\text {eq }}(\mathrm{mg} / \mathrm{g})=\left(C_{0}-C_{\mathrm{f}}\right) \cdot V / M$

where $C_{0}$ is the initial $\mathrm{Cr}(\mathrm{VI})$ concentration $(\mathrm{mg} / \mathrm{L}), C_{\mathrm{f}}$ is the final $\mathrm{Cr}(\mathrm{VI})$ concentration $(\mathrm{mg} / \mathrm{L}), V$ is the solution volume $(L)$, and $M$ is the total bacterial cell biomass $(g)$ at equilibrium (Buchko et al. 1999).
As demonstrated previously, Morganella morganii STB5 cells do not store or accumulate $\mathrm{Cr}(\mathrm{VI})$ without conversion, as no $\mathrm{Cr}(\mathrm{VI})$ release could be observed following the destruction of bacterial cell membranes through sonication (Ergul-Ulger et al. 2014). It was therefore assumed that all decreases in $\mathrm{Cr}(\mathrm{VI})$ concentrations are due to reduction and the removed $\mathrm{Cr}(\mathrm{VI})$ is reduced entirely to the stable $\mathrm{Cr}(\mathrm{III})$.

\section{Adsorption isotherms and kinetics studies}

Adsorption isotherm coefficients were determined upon three isotherm models (Langmuir, Freundlich and Toth) using the isotherm parameter fitting software IsoFit (Wagner et al. 2005). The order of reactions for $\mathrm{Cr}(\mathrm{VI})$ removal was predicted by plotting zero-, first-, second- and third-order plots of STB5/PS and STB5/PSU webs to calculate and compare their $R^{2}$ values for evaluation of the best fitting models.

\section{Scanning electron microscopy (SEM)}

Millimeter-length PS and PSU webs with and without bacterial immobilization were cut and prepared for SEM analysis to evaluate bacterial attachment before and after $\mathrm{Cr}(\mathrm{VI})$ bioremoval experiments. A modified protocol was utilized for SEM sample fixation (Greif et al. 2010). Briefly, samples were washed twice with PBS (phosphatebuffered saline) buffer and incubated overnight in $2.5 \%$ glutaraldehyde solution (prepared in PBS buffer) at room temperature. Samples were then washed twice by PBS buffer and dehydrated by immersion in a series of ethanolwater solutions (30-96\%). All fixed samples were coated with $5 \mathrm{~nm} \mathrm{Au-Pd}$ prior to SEM imaging (Quanta 200 FEG SEM, FEI Instruments, USA).

\section{Reusability and post-storage performances of STB5/ PS and STB5/PSU fibrous biocomposites}

$\mathrm{Cr}(\mathrm{VI})$ bioremoval studies were performed five times to evaluate the reusability of STB5/PS and STB5/PSU fibrous biocomposites. Prior to each cycle, biocomposites were washed with PBS buffer twice and then incubated overnight in this buffer to eliminate any unattached bacteria. $\mathrm{Cr}(\mathrm{VI})$ bioremoval experiments were performed with the parameters as described above (incubation at $150 \mathrm{rpm}$ and $30{ }^{\circ} \mathrm{C}$ for $72 \mathrm{~h}$ ). The initial $\mathrm{Cr}(\mathrm{VI})$ concentration was fixed at $25 \mathrm{mg} / \mathrm{L}$, the remaining $\mathrm{Cr}(\mathrm{VI})$ concentrations were measured at 0 and $72 \mathrm{~h}$, and the percentile removal of $\mathrm{Cr}(\mathrm{VI})$ was calculated using these results. Each cycle was ended after $72 \mathrm{~h}$ of incubation, and washing steps were repeated for each biocomposite before starting the next cycle. All tests were done in triplicate. 
Fig. 2 SEM micrographs of a PS and b PSU webs without bacterial immobilization, and c STB5-immobilized PS and d STB5-immobilized PSU webs after 30 days of incubation for bacterial immobilization
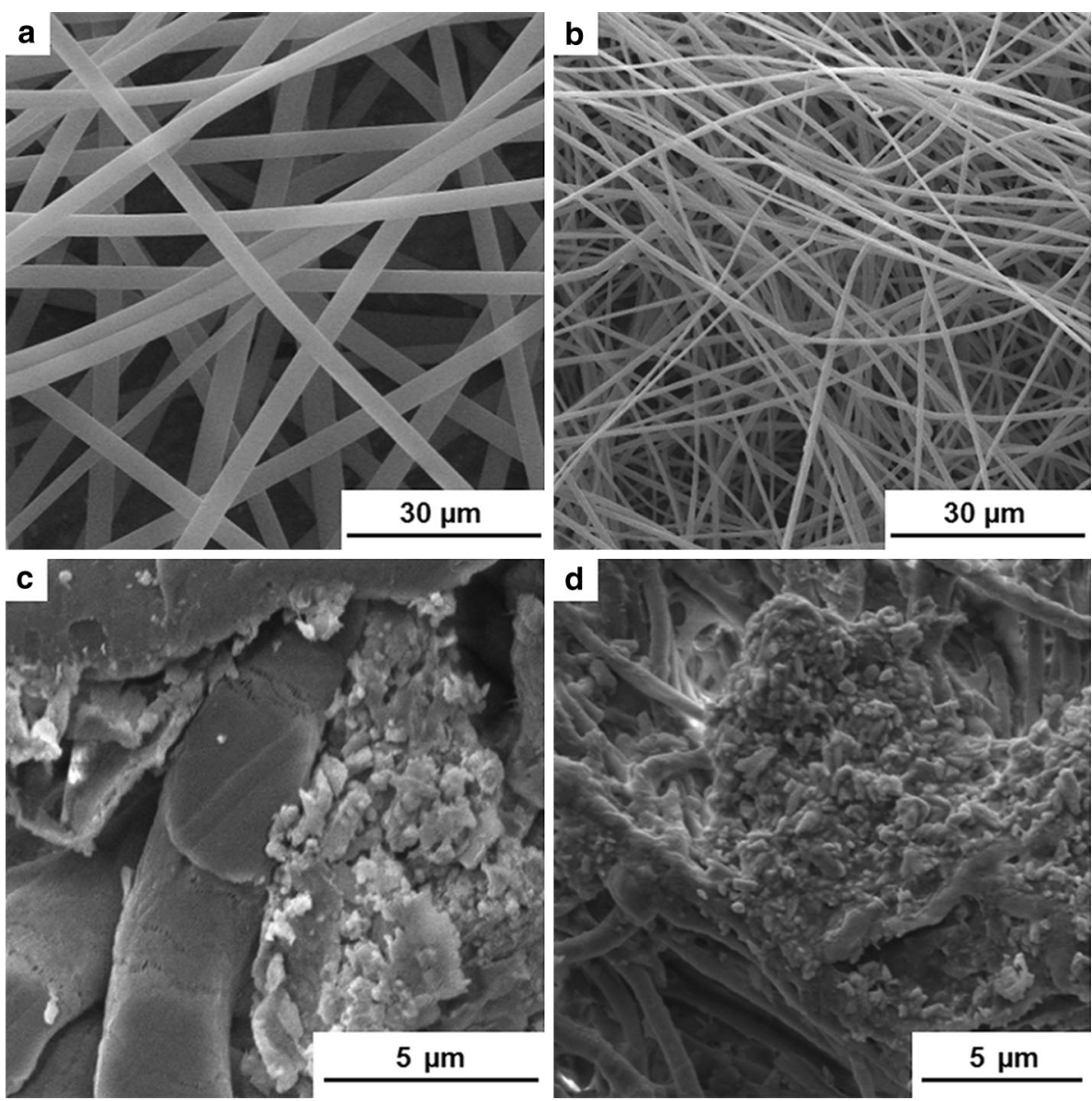

\section{Results and discussion}

\section{Attachment of bacterial cells on PS and PSU webs}

Polystyrene (PS)- and polysulfone (PSU)-based polymeric materials can be used for water purification as membranes or filters, and there are several reports in the literature about the applications of these polymers as electrospun nanofibers for water filtering purposes (Gopal et al. 2007; Roso et al. 2008; Uyar et al. 2009, 2010). In this study, high-surface area electrospun PS and PSU fibers were used as substrates for bacterial attachment and the combined system was subsequently utilized for $\mathrm{Cr}$ (VI) removal. SEM analysis was performed to assess the extent of bacterial attachment on the fibrous surfaces, and an incubation period of 30 days was found to be required for robust bacterial adhesion. SEM images of PS and PSU webs before bacterial adhesion are shown in Fig. 2a, b. The average diameters of PS and PSU fibers were found as $2 \mu \mathrm{m}$ and $0.8 \mu \mathrm{m}$, respectively. Furthermore, both electrospun webs were tested for hydrophobicity differences by contact angle (CA) measurements. PS webs were found to be relatively more hydrophobic $\left(\mathrm{CA}: 146.13^{\circ} \pm 4.74\right)$ compared to PSU webs (CA: $126.5^{\circ} \pm 5.91$ ), although both webs have hydrophobic character. Figure 2c, d show that bacterial cells attached strongly on PS and PSU fibrous surfaces after 30 days of incubation, suggesting that both webs are suitable for strong bacterial adhesion. The bacterial cells formed biofilm structures by adhering to each other and to the surrounding PS and PSU fibers. Bacterial adhesion at this stage was found to be sufficient for further studies, and $\mathrm{Cr}(\mathrm{VI})$ bioremoval experiments were started with bacteria-immobilized PS and PSU webs.

\section{Cr(VI) bioremoval capability of STB5/PS and STB5/ PSU biocomposite webs}

Initially, free STB5 cells were tested for $\mathrm{Cr}(\mathrm{VI})$ removal at five different $\mathrm{pH}$ levels to find out the optimal $\mathrm{pH}$ level for the removal process (Fig. 3a). Neutral pH (pH 7.0) was found as the optimal level for $\mathrm{Cr}$ (VI) remediation by STB5 cells, and the $\mathrm{pH}$ levels of further studies were adjusted accordingly. Since the highest $\mathrm{Cr}(\mathrm{VI})$ removal performance was achieved at neutral conditions instead of acidic environments, it was inferred that biological removal rather than adsorption is the primary removal practice for STB5 

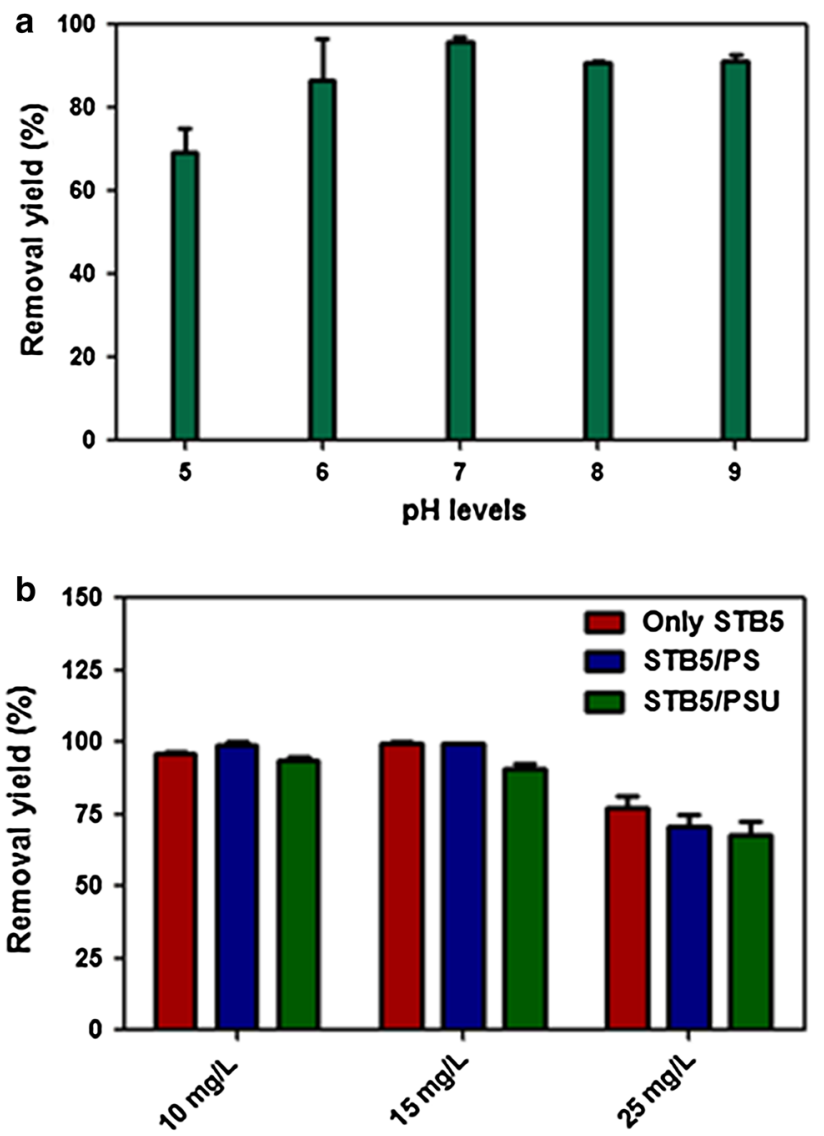

Initial $\mathrm{Cr}(\mathrm{VI})$ concentration

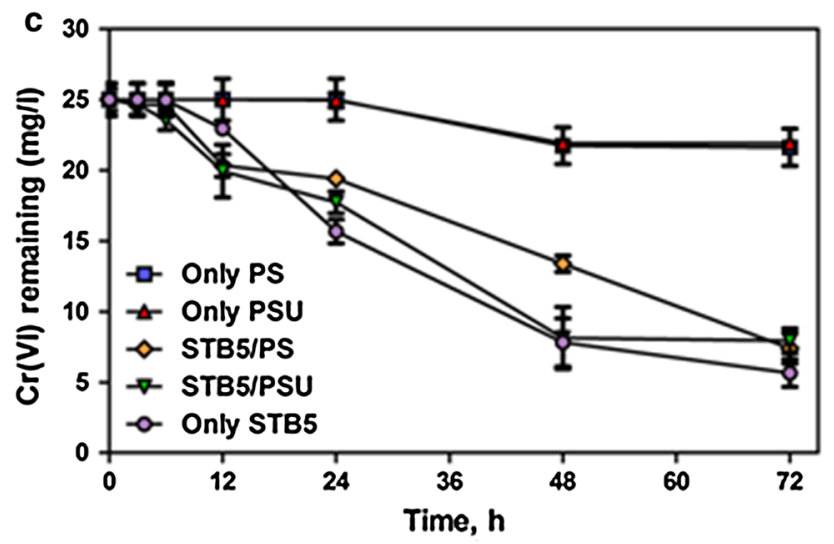

Fig. $3 \mathrm{Cr}(\mathrm{VI})$ bioremoval profiles of a free STB5 cells at different pH levels, b only STB5, STB5/PS and STB5/PSU samples at different initial $\mathrm{Cr}(\mathrm{VI})$ concentrations and $\mathbf{c}$ only STB5, only PS, only PSU, STB5/PS and STB5/PSU samples at an initial concentration of $25 \mathrm{mg} / \mathrm{L}$. Error bars represent mean of three independent replicates

cells. STB5/PS and STB5/PSU biocomposite webs have shown efficient removal of $\mathrm{Cr}(\mathrm{VI})$ at three different initial concentrations $(10,15$ and $25 \mathrm{mg} / \mathrm{L})$ within $72 \mathrm{~h}$, and their $\mathrm{Cr}(\mathrm{VI})$ removal profiles are comparable to free bacterial cells, suggesting that the biocomposites can remediate $\mathrm{Cr}(\mathrm{VI})$ as effectively as freely floating cells and the results are highly promising for further $\mathrm{Cr}(\mathrm{VI})$ remediation studies (Fig. 3b). Bacteria-free PS and PSU webs have shown very similar and slight decreases (13.5 and $12.3 \%$, respectively) in the initial $\mathrm{Cr}(\mathrm{VI})$ concentration (Fig. 3c), possibly due to adsorption, implying that the $\mathrm{Cr}(\mathrm{VI})$ remediation capability of STB5/PS and STB5/PSU biocomposites is primarily due to the presence of bacterial cells. As demonstrated in Table 1 , the $Q_{\text {eq }}$ (removal capacity at equilibrium) values of free STB5 cells are always higher than STB5/PS and STB5/PSU webs, while $Q_{\text {eq }}$ values of STB5/PS are following this sample generally. Two different types of polymeric webs were utilized as carrier matrices for bacterial immobilization, and PS was found to be a slightly better carrier matrix in terms of $\mathrm{Cr}(\mathrm{VI})$ removal capacity of its bacteria-immobilized form, possibly due to its more hydrophobic nature. It is known that gram-negative bacteria including Morganella morganii have hydrophobic surfaces because of the high lipid content on their cell walls, and hydrophobic bacteria have a preference to adhere on hydrophobic surfaces via hydrophobic interactions (Kochkodan et al. 2008; Giaouris et al. 2009). Therefore, hydrophobicity differences might play an important role on the adhesion of STB5 cells, and higher bacterial immobilization on PS web surfaces contributed to higher $\mathrm{Cr}(\mathrm{VI})$ removal performances by STB5/PS samples. Nonetheless, considerable amounts of $\mathrm{Cr}(\mathrm{VI})$ were removed in all experiments, suggesting that both biocomposites are promising candidates as supportive systems for conventional $\mathrm{Cr}(\mathrm{VI})$ remediation techniques. Since the biocomposites can work under non-acid-treated environments, such type of remediation can be applied in natural environments and allows the continuity of the remediation process.

\section{Evaluation of adsorption isotherm coefficients and reaction kinetics}

Adsorption isotherm plots for three different tested models (Langmuir, Freundlich and Toth) are presented in Fig. S1, and adsorption isotherm coefficients with their estimated values are listed in Table S1. While STB5/PSU fits well to each of the tested models, only STB5 and STB5/PS samples do not fit to any of the tested models, and thus the adsorption isotherm coefficients of these samples were not discussed. It was concluded that biological removal has the leading role in $\mathrm{Cr}(\mathrm{VI})$ remediation by free or immobilized bacteria, since adsorption isotherm coefficients fit only in one sample and the removal process performs best at neutral conditions where biological processes and enzymatic activity are more active usually. The highest correlation was observed in Langmuir model for STB5/PSU sample with the Ry ${ }^{2}$ value of 0.997 , suggesting that the dye removal process might be homogenous and monolayeric 
Table 1 Removal capacities of only STB5, STB5/PS and STB5/PSU samples at equilibrium under different initial Cr(VI) concentrations, measured at the end of the $72 \mathrm{~h}$ removal period

\begin{tabular}{llccc}
\hline Sample name & Initial concentration $\left(C_{0}\right)(\mathrm{mg} / \mathrm{L})$ & Removed $\mathrm{Cr}(\mathrm{VI})$ amount $(\mathrm{mg} / \mathrm{L})$ & $Q_{\text {eq }}(\mathrm{mg} / \mathrm{g})$ & $64.83 \pm 5.68$ \\
\hline Only STB5 & 10 & 9.56 & $63.49 \pm 4.3$ & 95.8 \\
STB5/PS & 10 & 9.36 & $63.64 \pm 7.59$ & 93.79 \\
STB5/PSU & 10 & 9.39 & $101.35 \pm 14.5$ & 99.56 \\
Only STB5 & 15 & 14.95 & $101.11 \pm 15.3$ & 99.47 \\
STB5/PS & 15 & 14.91 & $84.9 \pm 4.2$ & 90.78 \\
STB5/PSU & 15 & 12.52 & $131.2 \pm 12.4$ & 77.41 \\
Only STB5 & 25 & 19.35 & $119.3 \pm 7.65$ & 70.41 \\
STB5/PS & 25 & 17.60 & $115.7 \pm 11.2$ & 68.27 \\
STB5/PSU & 25 & 17.07 &
\end{tabular}

$T=30{ }^{\circ} \mathrm{C}$, agitation rate: $150 \mathrm{rpm}$, average bacterial biomass concentration $0.15 \pm 0.03 \mathrm{~g} / \mathrm{L}$

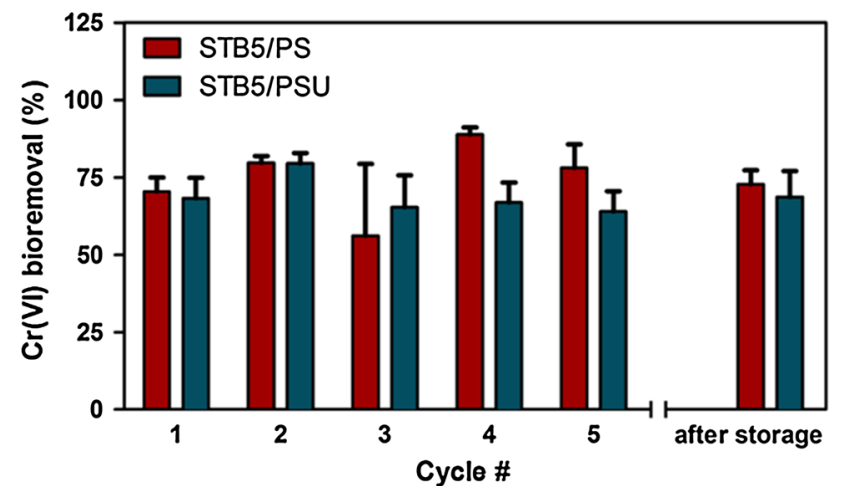

Fig. 4 Reusability and post-storage test results of STB5/PS and STB5/ PSU biocomposite webs for an initial concentration of $25 \mathrm{mg} / \mathrm{L}$. Error bars represent mean of three independent replicates

for this sample (Ergul-Ulger et al. 2014). The maximum removal capacity $\left(Q_{\max }\right)$ of STB5/PSU was measured as $139.83 \mathrm{mg} / \mathrm{g}$ under this model.

According to the reaction kinetics studies, it was observed that while STB5/PS fits better for zero-order reactions, only STB5 and STB5/PSU samples fit better for first-order reactions (Table S1). It has been reported that while enzyme-catalyzed reactions often fall under the zeroorder mechanism (Tinoco et al. 1996), Cr(VI) reduction kinetics can fit under the first-order model (Lugo-Lugo et al. 2010), as previously observed by another bacteriaimmobilized PSU web sample (San-Keskin et al. 2015a, b).

\section{Reusability and applicability of STB5/PS and STB5/ PSU biocomposites}

The potential of long-term $\mathrm{Cr}(\mathrm{VI})$ removal with STB5/PS and STB5/PSU biocomposites was evaluated through a reuse test where the materials were washed and used for $\mathrm{Cr}(\mathrm{VI})$ removal in five consecutive cycles. Figure 4 shows the performance values of each cycle and the post-storage performances of both biocomposites following 15 days of storage at $4{ }^{\circ} \mathrm{C}$ in a closed moist environment. At the end of the reusability test, an average removal capacity of $74.63 \%$ was achieved for STB5/PS, while this value was $63.95 \%$ for STB5/PSU, indicating that both biocomposites retain their $\mathrm{Cr}(\mathrm{VI})$ removal capacity, and the STB5/PS biocomposite was relatively more efficient for continual $\mathrm{Cr}(\mathrm{VI})$ bioremoval. The results of the post-storage experiment were also promising, as 72.79 and $68.65 \% \mathrm{Cr}(\mathrm{VI})$ removal was observed for STB5/PS and STB5/PSU following 15 days of storage, demonstrating that both biocomposites can be stored for short periods of time without losing their $\mathrm{Cr}(\mathrm{VI})$ removal capabilities. These results as a whole are very promising and after process optimization, STB5/PS and STB5/PSU biocomposites may be utilized repeatedly for $\mathrm{Cr}(\mathrm{VI})$ removal and can be stored for longer periods of time, thus serving as reusable and storable materials for the remediation of $\mathrm{Cr}(\mathrm{VI})$ from aqueous environments. Following reusability and storage tests, the biocomposites were washed several times with PBS buffer and fixed for SEM analysis. Figure 5 shows bacterial biofilms are present on both PS and PSU webs, indicating that bacterial cells survive throughout the reusability experiments. It can be inferred that washing and reuse of bacteria-immobilized PS and PSU web samples did not lead to a viable decrease in the quantity of bacterial biofilms, and the bacterial cells are likely to be preserved on both PS and PSU webs.

Heavy metal remediation of aquatic systems is a substantial issue, and greener approaches are becoming more popular as of late (Flathman and Lanza 1998; Mulligan et al. 2001; Davis et al. 2003; Gavrilescu 2004; Congeevaram et al. 2007). In this study, a $\mathrm{Cr}(\mathrm{VI})$-reducing bacterial strain was immobilized on electrospun PS and PSU webs, and $\mathrm{Cr}(\mathrm{VI})$ removal performances of these newly 
Fig. 5 SEM micrographs of STB5 immobilized a, b PS and c, d PSU webs after the reusability tests, showing robust attachment of bacterial biofilms on fibrous surfaces at $\mathbf{a}-$ $\mathbf{c} \times 5000$ and $\mathbf{b}-\mathbf{d} \times 10,000$ magnification
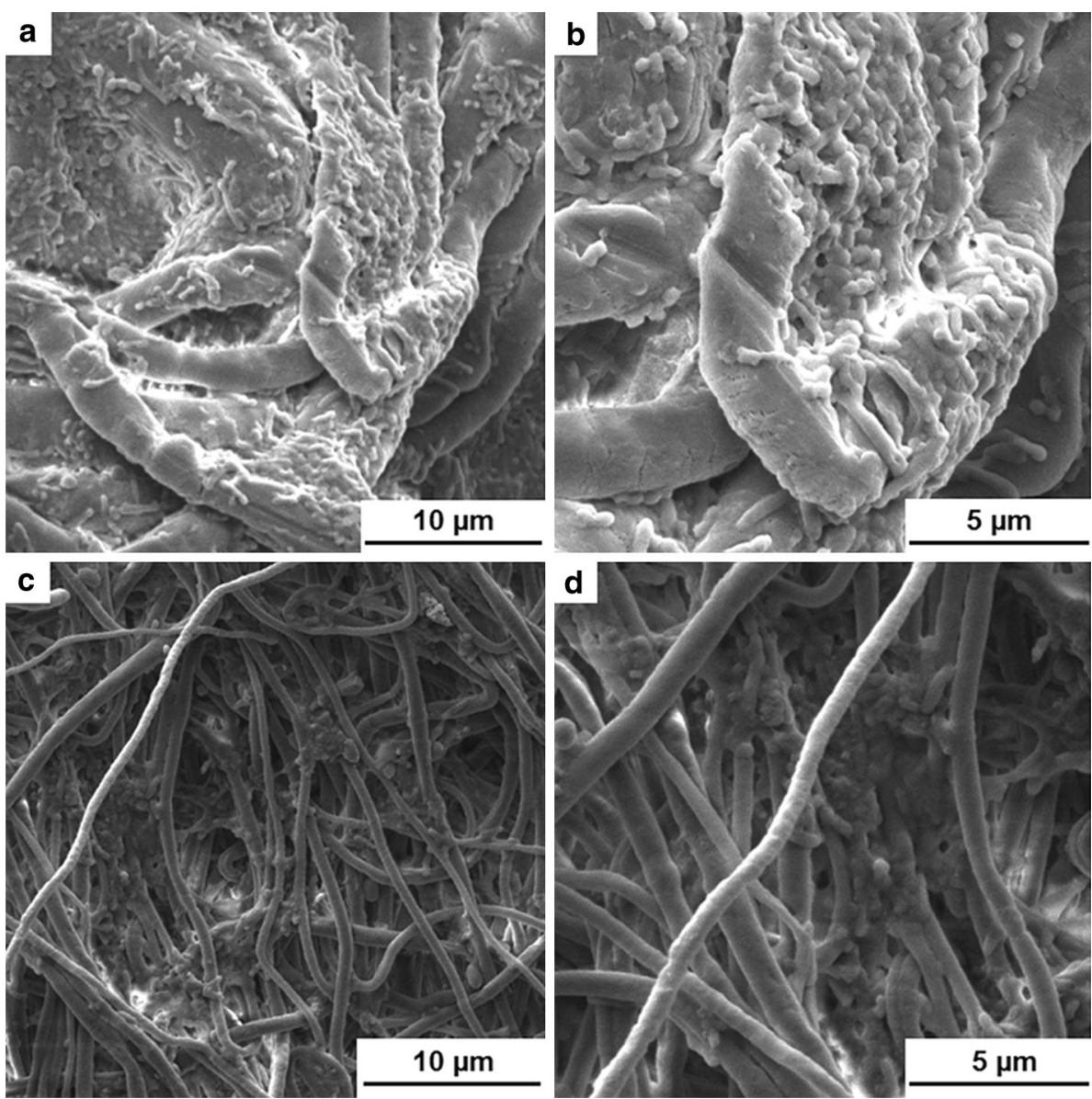

generated biocomposites were evaluated. It was found that bacterial cells could attach strongly on fibrous surfaces, the biocomposites have the capability to remediate $\mathrm{Cr}(\mathrm{VI})$ as effectively as free STB5 cells, they can be reused for several cycles of $\mathrm{Cr}(\mathrm{VI})$ removal and they can be stored without losing their $\mathrm{Cr}$ (VI) bioremoval capabilities. Similar approaches have been proposed in the literature for remediation of water contaminants, and there are some examples for treatment of water systems by using biointegrated electrospun nanofibrous structures. A novel biocomposite has been produced by Eroglu and colleagues for nitrate bioremoval by immobilizing microalgal cells on electrospun chitosan nanofiber mats (Eroglu et al. 2012). In very recent studies, specific bacterial or algal strains have been immobilized on electrospun nanofibrous webs for ammonium bioremoval (Sarioglu et al. 2013), methylene blue dye biodegradation (San et al. 2014), reactive dye biodegradation (San-Keskin et al. 2015a, b), anionic surfactant biodegradation (Sarioglu et al. 2015) and simultaneous removal of $\mathrm{Cr}(\mathrm{VI})$ and a reactive dye (San-Keskin et al. 2015a, b). In the current study, Cr(VI) was selected as the target contaminant, and two different bacteria-immobilized electrospun fibrous webs were prepared to evaluate their $\mathrm{Cr}(\mathrm{VI})$ remediation profiles. It was found that $\mathrm{Cr}(\mathrm{VI})$ removal performance of STB5 strain decreases at higher concentrations, suggesting that this strain and the biocomposites may be more suitable for bioremediation of freshwater systems with lower amounts of $\mathrm{Cr}(\mathrm{VI})$ contamination. By increasing the coverage area of immobilized bacteria in STB5/PS and STB5/PSU webs, or optimizing the bacterial growth conditions, it is likely that higher removal rates for $\mathrm{Cr}(\mathrm{VI})$ can be achieved for both biocomposites.

In brief, $\mathrm{Cr}$ (VI) removal by STB5/PS and STB5/PSU biocomposites is handy, effective and easily applicable. The results suggest that both biocomposites have the potential to be further developed for use in $\mathrm{Cr}$ (VI) remediation from aqueous environments.

\section{Conclusion}

In this report, two novel biocomposite materials which are produced by immobilizing a $\mathrm{Cr}(\mathrm{VI})$-removing bacterial strain on electrospun PS and PSU fibrous webs are described. SEM micrographs of STB5/PS and STB5/PSU 
web samples have shown robust bacterial adhesion on both fibrous surfaces after incubation time, and no significant differences were observed for the bacterial immobilization even after five cycles of reuse. It was found that the $\mathrm{Cr}(\mathrm{VI})$ removal capability of STB5/PS and STB5/PSU biocomposites is based primarily on bacterial activity and is comparable to the $\mathrm{Cr}(\mathrm{VI})$ removal performance of free bacterial cells. Considerable amounts of $\mathrm{Cr}(\mathrm{VI})$ were removed by both STB5/PS and STB5/PSU biocomposite webs at all tested concentrations, yet the removal performances were started to decrease at higher concentrations, suggesting that the biocomposites can perform best at a defined concentration range. STB5/PS has shown higher removal performances than STB5/PSU in most experiments, implying that higher hydrophobic surfaces of PS webs allowed higher bacterial immobilization for hydrophobic STB5 cells, and thereby higher $\mathrm{Cr}(\mathrm{VI})$ removal performances. Both biocomposites were found to be reusable for several cycles and could be stored for short periods of time without exhibiting losses in attached cell numbers or $\mathrm{Cr}(\mathrm{VI})$ remediation capabilities, proposing that they may be used repeatedly for $\mathrm{Cr}(\mathrm{VI})$ remediation. Freestanding STB5/PS and STB5/PSU biocomposites may be easily utilized for continuous $\mathrm{Cr}(\mathrm{VI})$ remediation in freshwater sources by immersing them into the contaminated source.

Acknowledgments The Scientific and Technological Research Council of Turkey (TUBITAK, project \#114Y264) is acknowledged for funding the research. Dr. Uyar acknowledges The Turkish Academy of Sciences-Outstanding Young Scientists Award Program (TUBA-GEBIP) for the partial funding of the research. A. Celebioglu acknowledges TUBITAK project \#113Y348 for postdoctoral fellowship. O. F. Sarioglu acknowledges TUBITAK BIDEB (2211-C) for National Ph.D. Scholarship. The authors thank Dr. N. Oya San-Keskin for technical assistance and Pelin Toren for Contact Angle measurements and Alper Devrim Ozkan for his fruitful discussions.

\section{References}

Al-Gheethi AAS, Norli I, Lalung J, Azlan AM, Farehah ZAN, Kadir MOA (2014) Biosorption of heavy metals and cephalexin from secondary effluents by tolerant bacteria. Clean Technol Environ Policy 16(1):137-148

Bankar AV, Kumar AR, Zinjarde SS (2009) Removal of chromium (VI) ions from aqueous solution by adsorption onto two marine isolates of Yarrowia lipolytica. J Hazard Mater 170:487-494

Buchko CJ, Chen LC, Shen Y, Martin DC (1999) Processing and microstructural characterization of porous biocompatible protein polymer thin films. Polymer 40:7397-7407

Chauhan D, Durivedi J, Sankaramakrishnan N (2014) Novel chitosan/ $\mathrm{PVA} /$ zerovalent iron biopolymeric nanofibers with enhanced arsenic removal applications. Environ Sci Pollut Res 21: 9430-9442

Congeevaram S, Dhanarani S, Park J, Dexilin M, Thamaraiselvi K (2007) Biosorption of chromium and nickel by heavy metal resistant fungal and bacterial isolates. $\mathrm{J}$ Hazard Mater 146:270-277

Davis TA, Volesky B, Mucci A (2003) A review of the biochemistry of heavy metal biosorption by brown algae. Water Res $37: 4311-4330$

Ergul-Ulger Z, Ozkan AD, Tunca E, Atasagun S, Tekinay T (2014) Chromium(VI) biosorption and bioaccumulation by live and acid-modified biomass of a novel Morganella morganii isolate. Sep Sci Technol 49:907-914

Eroglu E, Agarwal V, Bradshaw M, Chen X, Smith SM, Raston CL, Iyera KS (2012) Nitrate removal from liquid effluents using microalgae immobilized on chitosan nanofiber mats. Green Chem 14:2682-2685

Flathman PE, Lanza GR (1998) Phytoremediation: current views on an emerging green technology. J Soil Contam 7:415-432

Gavrilescu M (2004) Removal of heavy metals from the environment by biosorption. Eng Life Sci 4:219-232

Giaouris E, Chapot-Chartier MP, Briandet R (2009) Surface physicochemical analysis of natural Lactococcus lactis strains reveals the existence of hydrophobic and low charged strains with altered adhesive properties. Int J Food Microbiol 131:2-9

Gopal R, Kaur S, Feng CY, Chan C, Ramakrishna S, Tabe S, Matsuura T (2007) Electrospun nanofibrous polysulfone membranes as pre-filters: particulate removal. J Membr Sci 289:210-219

Greif D, Wesner D, Regtmeier J, Anselmetti D (2010) High resolution imaging of surface patterns of single bacterial cells. Ultramicroscopy 110:1290-1296

Hall-Stoodley L, Costerton JW, Stoodley P (2004) Bacterial biofilms: from the natural environment to infectious diseases. Nat Rev Microbiol 2:95-108

Kilic NK, Donmez G (2008) Environmental conditions affecting exopolysaccharide production by Pseudomonas aeruginosa, Micrococcus sp., and Ochrobactrum sp. J Hazard Mater 154:1019-1024

Klein S, Kuhn J, Avrahami R, Tarre S, Beliavski M, Green M, Zussman E (2009) Encapsulation of bacterial cells in electrospun microtubes. Biomacromolecules 10:1751-1756

Klein S, Avrahami R, Zussman E, Beliavski M, Tarre S, Green M (2012) Encapsulation of Pseudomonas sp. ADP cells in electrospun microtubes for atrazine bioremediation. J Ind Microbiol Biotechnol 39:1605-1613

Kochkodan V, Tsarenko S, Potapchenko N, Kosinova V, Goncharuk V (2008) Adhesion of microorganisms to polymer membranes: a photobactericidal effect of surface treatment with $\mathrm{TiO}_{2}$. Desalination 220:380-385

Liu Y, Gan L, Chen Z, Megharaj M, Naidu R (2012) Removal of nitrate using Paracoccus sp. YF1 immobilized on bamboo carbon. J Hazard Mater 229-230:419-425

Lugo-Lugo V, Barrera-Díaz C, Bilyeub B, Balderas-Hernández P, Ureña-Nuñez F, Sánchez-Mendieta V (2010) Cr(VI) reduction in wastewater using a bimetallic galvanic reactor. J Hazard Mater 176:418-425

Mishra S, Doble M (2008) Novel chromium tolerant microorganisms: isolation, characterization and their biosorption capacity. Ecotoxicol Environ Saf 71:874-879

Mulligan CN, Yong RN, Gibbs BF (2001) Remediation technologies for metal-contaminated soils and groundwater: an evaluation. Eng Geol 60:193-207

Pinchuk L (1989) US Patent 4,882,148

Quintelas C, Fernandes B, Castro J, Figueiredo H, Tavares T (2008) Biosorption of $\mathrm{Cr}(\mathrm{VI})$ by three different bacterial species supported on granular activated carbon: a comparative study. J Hazard Mater 153:799-809

Quintelas C, Fonseca B, Silva B, Figueiredo H, Tavares T (2009) Treatment of chromium(VI) solutions in a pilot-scale bioreactor 
through a biofilm of Arthrobacter viscosus supported on GAC. Bioresour Technol 100:220-226

Roso M, Sundarrajan S, Plizska D, Ramakrishna S, Modesti M (2008) Multifunctional membranes based on spinning technologies: the synergy of nanofibers and nanoparticles. Nanotechnology 19:285707

San NO, Celebioglu A, Tumtas Y, Uyar T, Tekinay T (2014) Reusable bacteria immobilized electrospun nanofibrous webs for decolorization of methylene blue dye in wastewater treatment. RSC Adv 4:32249-32255

San-Keskin NO, Celebioglu A, Uyar T, Tekinay T (2015a) Microalgae immobilized nanofibrous web for removal of reactive dyes from wastewater. Ind Eng Chem Res 54:5802-5809

San-Keskin NO, Celebioglu A, Sarioglu OF, Ozkan AD, Uyar T, Tekinay $\mathrm{T}$ (2015b) Removal of a reactive dye and hexavalent chromium by a reusable bacteria attached electrospun nanofibrous web. RSC Adv 5:86867-86874

Sarioglu OF, Yasa O, Celebioglu A, Uyar T, Tekinay T (2013) Efficient ammonium removal from aquatic environments by Acinetobacter calcoaceticus STB1 immobilized on an electrospun cellulose acetate nanofibrous web. Green Chem 15:2566-2572

Sarioglu OF, Celebioglu A, Tekinay T, Uyar T (2015) Evaluation of contact time and fiber morphology on bacterial immobilization for development of novel surfactant degrading nanofibrous webs. RSC Adv 5:102750-102758

Tinoco I, Sauer K, Wang JC (1996) Physical chemistry: principles and applications in biological sciences. Prentice-Hall, Englewood Cliffs
US EPA (1992) Chromium, Hexavalent (Colorimetric). United States Environmental Protection Agency. http://www.epa.gov/solid waste/hazard/testmethods/sw846/pdfs/7196a.pdf. Accessed 05 Oct 2015

US EPA (2010) Chromium-6 in drinking water. United States Environmental Protection Agency. http://water.epa.gov/drink/ contaminants/basicinformation/upload/Chromium6inDrinking Water.pdf. Accessed 05 Oct 2015

Uyar T, Havelund R, Nur Y, Hacaloglu J, Besenbacher F, Kingshott P (2009) Molecular filters based on cyclodextrin functionalized electrospun fibers. J Membr Sci 332:129-137

Uyar T, Havelund R, Hacaloglu J, Besenbacher F, Kingshott P (2010) Functional electrospun polystyrene nanofibers incorporating alpha, beta and gamma cyclodextrins: comparison of molecular filter performance. ACS Nano 4:5121-5130

Wagner H, Siebert T, Ellerby DJ, Marsh RL, Blickhan R (2005) ISOFIT: a model-based method to measure muscle-tendon properties simultaneously. Biomech Model Mechanobiol 4:10-19

Xu R, Si Y, Li F, Zhang B (2015) Enzymatic removal of paracetamol from aqueous phase: horseradish peroxidase immobilized on nanofibrous membranes. Environ Sci Pollut Res 22:3838-3846

Yang A, He M, Wang G (2009) Removal of toxic chromate using free and immobilized $\mathrm{Cr}(\mathrm{VI})$-reducing bacterial cells of Intrasporangium sp. Q5-1. World J Microbiol Biotechnol 25:1579-1587

Zahoor A, Rehman A (2009) Isolation of Cr(VI) reducing bacteria from industrial effluents and their potential use in bioremediation of chromium containing wastewater. J Environ Sci 21:814-820 